JIIP: Jurnal IImiah IImu Pemerintahan

Vol. 6, No. 1, Tahun 2021

DOI: $10.14710 /$ jiip.v6i1.10075

\title{
Aktivis Dakwah di Tengah Percaturan Politik Kampus: \\ Dinamika Gerakan Keislaman di Universitas Diponegoro
}

\author{
Hendra Try Ardianto ${ }^{1}$ \\ ${ }^{1}$ Prodi Ilmu Pemerintahan, Universitas Diponegoro
}

Dikirimkan: 8 Januari 2021

Direvisi: 23 Februari 2021

Diterbitkan: 25 Maret 2021

\section{INTISARI}

Artikel ini menyoroti bagaimana dinamika gerakan aktivis dakwah di tengah percaturan politik kampus. Lokus dari percaturan politik ini adalah seputar perebutan posisi ketua di organisasi intrakampus, baik organisasi kerohanian maupun Badan Eksekutif Mahasiswa (BEM). Dengan mengandalkan pada metode kualitatif deskriptif, penelitian ini menggali data dari aktor-aktor yang terlibat dalam kontestasi politik kampus, seperti aktivis dakwah, aktivis mahasiswa sekuler, dan pihak representasi perguruan tinggi. Temuannya menunjukkan bahwa kuatnya dominasi KAMMI sebagai representasi kelompok Tarbiyah dalam menduduki jabatan-jabatan strategis di organisasi intrakampus bukan terjadi karena kelompok keislaman lain yang meredup dan meninggalkan aktivitas dakwahnya. Sebaliknya, kelompok aktivis dakwah nonTarbiyah juga terbukti aktif dalam berbagai aktivitas dakwah, mulai dari kaderisasi, forum pengajian, bahkan diskusi seputar politik kontemporer di kampus. Kesimpulannya, posisi dominasi status quo yang disandang KAMMI bukan sekadar karena mereka aktif meramaikan masjid dan mengelola organisasi kerohanian, namun juga karena politik eksklusi yang mereka lakukan kepada kelompok lain, baik eksklusi secara kultural maupun struktural.

\section{KATA KUNCl}

aktivis dakwah; Tarbiyah; Badan Eksekutif Mahasiswa; politik kampus; perguruan tinggi

\section{Pendahuluan}

Aktivis dakwah kampus adalah orang yang secara aktif terlibat dalam keorganisasian agama suatu kampus, khususnya yang berafiliasi pada agama Islam. Kekhususan pada Islam saja karena istilah dakwah secara etimologis memiliki akar kata dari Bahasa Arab da'a-yad'u-da'watan, yang berarti "mengajak" atau "menyeru". Ini artinya, dakwah adalah aktivitas untuk mengajak orang lain menuju jalan Tuhan dan menuju arah kebaikan (QS. An Nahl: 125). Bentuk konkret dari aktivis dakwah kampus ini merujuk pada mereka yang aktif di organisasi seperti Lembaga Dakwah Kampus (LDK) atau di beberapa kampus lainnya dikenal dengan Kerohanian Islam (Rohis). Aktivis dakwah kampus akhir-akhir ini, terutama selama kurang lebih satu dekade terakhir telah menjadi objek riset banyak sekali peneliti. Hal ini terjadi karena dikaitkan dari fakta bahwa kaum muda merupakan sasaran dari merebaknya radikalisme.

\section{Korespodensi:}

Departemen Politik dan Pemerintahan, Fakultas Ilmu Sosial dan Ilmu Politik, Universitas Diponegoro, Jalan Professor Soedarto SH, Tembalang, Kec. Tembalang, Kota Semarang, Jawa Tengah 50139.

Email: hendratrya@lecturer.undip.ac.id 
Fakta di atas misalkan ditunjukkan dari viralnya video bai'at ribuan mahasiswa terhadap cita-cita pendirian Khilafah di Institut Tekhnologi Bandung (ITB) (Mediani, 2017). Selain itu, ada juga kasus penangkapan terduga teroris di Universitas Riau yang sempat menggemparkan publik (Kompas.com, 2018). Tidak itu saja, kenyataan bahwa Bahrun Naim, pentolan ISIS asal Indonesia merupakan alumnus Universitas Sebelas Maret adalah sedikit contoh dari keberadaan potensi radikalisme di kampus (BBC, 2016). Hal ini menunjukkan sebuah realita bahwa radikalisme tidak serta merta hanya menjangkiti kalangan tidak terdidik saja, namun juga kalangan kampus, baik mahasiswa ataupun dosen, merupakan kelompok yang rentan terpapar faham radikal.

Beberapa simtom di atas membuat banyak peneliti kemudian memberikan perhatian atas relasi kalangan pemuda aktivis dakwah terhadap radikalisme. Widyaningsih, Sumiyem, \& Kuntarto (2017) dalam artikelnya memaparkan bahwa para pemuda memiliki kerentanan yang tinggi untuk terpengaruh oleh paham radikal. Radikalisme ini bisa menyusup pada berbagai kegiatan keagamaan mahasiswa di kampus. Tidak hanya di tingkat perguruan tinggi, radikalisme pun bisa menyusup bagi siswa di tingkatan sekolah (Munip, 2012). Dalam penelitian Aidulsyah (2016: 282) menunjukkan bahwa kegiatan ekstrakurikuler di sekolah berupa Kerohanian Islam (Rohis) ada kalanya disusupi nilai-nilai yang bertentangan dengan nilai kewarganegaraan (citizenship) dan demokrasi. Kondisi seperti ini memang sangat mungkin terjadi, mengingat generasi muda memiliki kecenderungan lebih kuat dan besar untuk tergabung dalam gerakan sosial radikal dibandingkan dengan generasi tua (Azca, 2013: 27).

Meskipun penelitian terhadap aktivis dakwah kampus tidak selalu berujung pada kesimpulan potensi radikalisme, tetapi sebagian besar memberi titik perhatian pada seluk beluk dari pemikiran, karakter, dan persepsi para aktivis dakwah kampus. Iswanto (2017) misalnya, untuk melihat bagaimana pemikiran para aktivis dakwah kampus, ia memberikan perhatian pada literatur bacaan yang dibaca para aktivis dakwah di ITB. Tidak hanya itu, Isnaniah (2015) bahkan melakukan penelitian tentang jargon-jargon bahasa Arab yang dipakai oleh aktivis dakwah kampus di wilayah Surakarta. Selain literatur dan jargon, ada juga yang meneliti bagaimana peran masjid kampus sebagai media komunikasi dalam membentuk karakter para aktivis dakwah, sebagaimana diteliti oleh Tahir \& Cangara (2016) di lingkungan Universitas Hasanudin, Universitas Negeri Makassar, dan UIN Alauddin. Lebih jauh lagi, karena keraguannya atas Ke-Indonesia-an para aktivis dakwah kampus, Rofiq \& Bhakti (2018) bahkan harus menguji persepsi aktivis dakwah di Universitas Tidar tentang Pancasila, UUD 1945, NKRI, dan Bhinneka Tunggal Eka (dikenal dengan Empat Pilar Kehidupan Berbangsa dan Bernegara).

Selain beberapa penelitian di atas, ada juga beberapa peneliti yang menghubungkan sisi-sisi sosiologis dan psikologis dari perilaku para aktivis dakwah kampus ini. Darmawati (2013) misalkan, ia memberikan perhatian secara serius terhadap perubahan sosiologis dari perilaku sehari-hari dan cara berpakaian yang 
bergeser ke arah hal-hal berbasis simbol-simbol keislaman. Ada juga penelitian yang mengaitkan psychological well-being, yakni dimensi penerimaan diri, hubungan positif dengan orang lain, otonomi, tujuan hidup, pertumbuhan pribadi, dan penerimaan lingkungan sekitar para aktivis dakwah kampus (Fajar, 2017). Sampai-sampai, ada penelitian yang mencoba membandingan motivasi berprestasi antara aktivis dakwah dengan non-aktivis dakwah (Trisno, 2010).

Melihat dari penelitian tentang aktivis dakwah kampus pada tempo satu dekade terakhir ini, terlihat masih jarang yang mengelaborasi tentang dinamika para aktivis dakwah dalam percaturan politik di internal kampus. Adapun maksud dari percaturan politik kampus adalah perkara perebutan jabatan strategis pada kepengurusan di organisasi intrakampus, baik organisasi kerohanian maupun Badan Eksekutif Mahasiswa (BEM). Padahal jamak diketahui publik bahwa percaturan politik di organisasi intrakampus seringkali menjadi arena perebutan kuasa antar aktivis mahasiswa, tidak terkecuali aktivis dakwah kampus.

Meskipun jarang, sudah ada penelitian-penelitian sebelumnya terkait dinamika aktivisme dakwah di kalangan mahasiswa, tetapi sebagian besar tidak memberikan titik tekan secara serius pada perebutan jabatan-jabatan strategis di organisasi instrakampus. Kamim, Azizi, Pratama, Haekal, \& Santoso (2018) misalnya, mereka sudah menunjukkan bagaimana dinamika pengaruh aktivis Jamaah Shalahudin dan LDK yang jauh lebih berpengaruh daripada Takmir Masjid UGM dalam memobilisasi sumber daya dakwah di kampus UGM. Namun demikian, artikel tersebut tidak sampai menyinggung bagaimana perebutan kuasa di organisasi intrakampus berlangsung. Di luar itu, memang sudah ada penelitian yang secara khusus menyoroti tentang sejarah panjang BEM dari awal hingga masa kini. Husin (2014) secara telaten dan jeli berhasil menjahit kesejarahan BEM dari masa ke masa, terutama di kampus UGM. Hanya saja analisisnya terlalu makro dan cenderung mengaitkan posisi BEM sebagai kelompok penekan terhadap isu-isu nasional. Tidak terlalu banyak dinamika keseharian bagaimana BEM diperebutkan antar kelompok mahasiswa pada penelitian itu.

Satu-satunya penelitian yang paling mendekati upaya melihat dinamika para aktivis dakwah dalam percaturan politik di internal kampus adalah buku Islamisme ala Kaum Muda Kampus: Dinamika Aktivisme Mahasiswa Islam di Universitas Gadjah Mada dan Universitas Indonesia di Era Pasca Soeharto karya Mohammad Zaki Arrobi. Dalam beberapa bagian di buku itu, Arrobi (2020) mengupas banyak hal bagaimana aktivis dakwah kampus terlibat dalam percaturan politik di internal kampus. Pada titik itu, maka artikel ini memiliki sedikit kemiripan dengan karya (Arrobi, 2020). Hanya saja, penulis akan melihat dinamika gerakan keislaman di Universitas Diponegoro (Undip), terutama dari sisi-sisi mikro dan politik keseharian (daily life politics) para aktivis dakwah di sana.

Pilihan penelitian terhadap Undip menjadi menarik karena pasca keluarnya Perpres No. 2 Tahun 2017 tentang Organisasi Masyarakat (selanjutnya Perppu Ormas), Undip pernah menjadi sorotan publik karena salah seorang profesor di Undip 
memberikan dukungan terhadap organisasi Hizbut Tahrir Indonesia yang dibubarkan pemerintah. Tidak tanggung-tanggung, M. Nasir selaku Menteri Ristekdikti saat itu, mengeluarkan ultimatum, "(Radikalisme di kampus -pen) Harus segera diselesaikan secara cepat dan tepat. Jika rektor tidak bisa menyelesaikannya, nanti rektor tersebut yang akan saya selesaikan. Jadi, tolong segera diselesaikan. Termasuk kalau terbukti, berikan sanksi tegasnya" (Setiawan, 2018).

Tulisan ini dikerjakan dari sebuah proses riset selama dua bulan, yakni November dan Desember 2018. Dengan mengandalkan pada metode penelitian kualitatif, penulis menggali data baik berupa wawancara maupun analisis dokumen. Ada cukup banyak informan yang diwawancara, mulai dari kelompok aktivis dakwah, kelompok mahasiswa non-dakwah, kelompok mahasiswa non-Islam, dan dosen-dosen di lingkungan Universitas Diponegoro. Sebaran informan yang beragam ini diharapkan mampu untuk menguji seberapa confirmability data yang diperoleh.

Ada tiga lokus yang akan menjadi unit analisis terkait dengan gambaran gerakan keislaman di Undip, yakni Masjid Kampus (Maskam), Lembaga Dakwah Kampus (LDK), dan Badan Eksekutif Mahasiswa (BEM). Maskam Undip adalah salah satu tempat dimana nyaris semua organisasi keislaman memanfaatkan keberadaannya untuk mendukung berbagai kegiatan di organisasinya masing-masing. Mereka bisa menggunakan Maskam Undip untuk kegiatan pengajian, kaderisasi, diskusi, mentoring, bahkan sekedar menggelar tahlilan. Sedangkan lembaga dakwah adalah wadah bagi mahasiswa muslim untuk mengekspresikan nilai-nilai keislaman dirinya di lingkungan kampus. Lembaga Dakwah ini ada di tingkat jurusan (biasa disebut LDJ), di tingkat fakultas (disebut LDF), dan di tingkat universitas, yakni UKM Indah Persaudaraan Islam atau dikenal dengan Insani. Adapun BEM sendiri bukanlah wadah organisasi mahasiswa muslim, namun fakta mencatat BEM selalu menjadi arena perebutan antar organisasi mahasiswa di lingkungan kampus, termasuk para aktivis dakwah.

\section{Tiga Lokus Arena Kontestasi}

Jika pemetaan aktivis dakwah dilakukan pada 3 lokus, yakni UKM Insani, BEM Undip, dan Masjid Kampus, maka ada satu fakta yang muncul, bahwa kelompok Kesatuan Aksi Mahasiswa Muslim (KAMMI) sebagai representasi kelompok Tarbiyah, nyaris mendominasi posisi struktural di 3 lokus tersebut. Kader-kader KAMMI selalu menduduki jabatan strategis di masing-masing organisasi, baik itu di Lembaga Dakwah Jurusan/Fakultas, di BEM dari tingkat fakultas hingga tingkat universitas, dan juga di Remaja Masjid Al Fatih di Maskam Undip. Kuatnya dominasi KAMMI bukan karena tiadanya eksistensi kelompok lain, semisal Himpunan Mahasiswa Islam (HMI), Persatuan Mahasiswa Islam Indonesia (PMII), Ikatan Mahasiswa Muhammadiyah (IMM), Keluarga Mahasiswa Nahdlatul Ulama (KMNU), dan lain sebagainya. Namun karena posisi KAMMI 
sudah menjadi status quo dan struktur organisasinya pun sudah dieksklusi hanya pada lingkaran kader KAMMI.

Sebelum ada UKM Insani, kegiatan dakwah kampus tingkat Universitas sudah di mulai pada awal 80-an oleh Lembaga Amal Islam (LAI) Undip. Beberapa tahun kemudian LAI Undip berganti nama menjadi Badan Amal Islam (BAI) Undip. Sampai dengan tahun 1995, namanya berubah menjadi UKM Rohis Undip karena adanya perubahan struktur kemahasiswaan Undip. Hingga akhirnya pada 26 Desember 2007 organisasi ini ditetapkan sebagai Unit Kegiatan Mahasiswa Indah Persaudaraan Islam (UKM INSANI). Insani adalah organisasi instra kampus, yang berkegiatan seputar kegiatan dakwah Islam. UKM ini sebagaimana UKM lain di Undip, mendapat dana dan perlakuan yang sama dari universitas.

Selain Insani, disetiap fakultas terdapat organisasi sejenis setingkat fakultas. Organisasi di tingkat fakultas ini biasa disebut dengan Rohis Fakultas atau Lembaga Dakwah Fakultas (LDF). Beberapa lainnya, ada di tingkat jurusan yang dikenal dengan Lembaga Dakwah Jurusan (LDJ). Masing-masing LDF atau LDJ memiliki nama berbedabeda. Saat ini ada 13 LDF dan 16 LDJ di UNDIP. Berikut ini daftar LDF dan LDJ yang penulis kutip dari website Insani.

1. Rohis Fakultas Teknik (Izzati)

2. Sie Kerohanian Islam Psikologi (Skripsi),

3. Madani Rohis FSM

4. Forum Silaturrahim Mahasiswa Muslim Ilmu Keperawatan ( Fosimmik)

5. Keluarga Mahasiswa Islam (Gamais) FKM

6. Al-Bahrain FPIK

7. Keluarga Muslim An-Nahl Peternakan

8. Forum Komunikasi Mahasiswa Islam (FKMI) D3 Teknik

9. Rohis Fakultas Ekonomi (Mizan)

10. Keluarga Mahasiswa Muslim Sastra (Kharisma) FIB

11. Forum Komunikasi Mahasiswa Muslim (FKMM) FISIP

12. Rohis Kedokteran Umum (KU)

13. Kelompok Studi Hukum Islam (KSHI) Hukum

Pada tingkatan Jurusan, 12 LDJ merupakan struktur dibawah Izzati Teknik, sedangkan 4 LDJ lainnya dibawah Rohis FSM, sedangkan LDF lain belum memiliki LDJ. Dari daftar di atas, menariknya adalah tidak dicantumkannya LDF Koordinator Kegiatan Islam (KKI) di Fakultas Hukum. KKI sebenarnya adalah rohis atau LDF Hukum, namun website Insani malah memasukkan Kelompok Studi Hukum Islam (KSHI) sebagai LDF. Padahal, KHSI sebenarnya kelompok studi yang lebih muda, dan bukan dikenal sebagai rohis di Fakultas Hukum. Ketika ditelusuri ternyata hal ini terjadi karena KKI selama ini tidak pernah berhasil dikuasai oleh kader-kader KAMMI. Kelompok HMI dan PMII yang 
selalu memegang jabatan struktural di KKI. Sebaliknya, KSHI adalah kelompok studi di lingkaran mahasiswa hukum yang sebagian besar diisi oleh kader-kader KAMMI.

Lepas dari mengapa KKI tidak dicantumkan dalam website Insani, pada umumnya LDF memiliki kegiatan berupa kajian rutin tiap pekan, mentoring bagi calon anggota/pengurus, kegiatan ibadah bersama, dan pengajian yang mengundang penceramah dari luar. Hanya secara garis besar, baik LDJ, LDF, maupun Insani, nyaris semuanya diiisi oleh kader dari KAMMI. Meskipun jumlahnya tidak bisa dipastikan, namun hampir setiap LDJ dan LDF, secara struktural diisi oleh kader KAMMI dari jabatan ketua hingga jabatan struktural di bawahnya. Artinya, secara keseharian, kultur KAMMI adalah kultur di setiap rohis di fakultas. Meski begitu, tidak semua anggota rohis fakultas adalah kader KAMMI. Ada beberapa diantara mereka berasal dari HMI, PMII, IMM dan KMNU, meski jumlahnya relatif kecil. Karena sedikitnya keterlibatan dari organisasi ekstra tersebut di LDF atau LDJ, banyak yang beranggapan rohis fakultas itu sama saja dengan KAMMI versi intrakampus. Ada kecenderungan hanya kader KAMMI yang bisa menjadi ketua LDJ atau LDF.

Dinamika kepemimpinan LDJ dan LDF bergantung pada konteks jurusan dan fakultas masing-masing, tetapi untuk Insani cenderung dikuasai oleh KAMMI. Hal ini dikonfirmasi dari proses kandidasi untuk 2 tahun, yakni 2017 dan 2018. Penguasaan KAMMI di Insani bisa jadi jauh lebih lama, tetapi data realible yang bisa dijangkau penulis hanya 2 tahun terakhir. Dalam kandidasi Mas'ul (Ketua) Insani 2017, dari 3 calon, hanya 1 yang bukan kader KAMMI. Ketiganya adalah Muhammad Rosyid Ridho (FEB 2015) dan Ilham Fathurohman (FPIK 2015) yang merupakan kader KAMMI, sedangkan hanya Makhrul Hamdi (FT 2015) yang bukan kader KAMMI. Adapun yang terpilih adalah Muhammad Rosyid Ridho (FEB 2015) yang berasal dari KAMMI.

Begitupun dengan kandidasi Mas'ul Insani 2018, dari 3 calon diketahui 2 calon diantaranya adalah anak KAMMI, yakni Rizky Tri Utomo (FEB 2016) dan Raden Muhamad Iqbal (Fisip 2016). Sedangkan 1 calon lainnya, Muhammad Budi Buchari Harahap (FEB 2016), belum diketahui afiliasi organisasi ekstranya oleh penulis. Meski bukan KAMMI, tracking media sosial dari penulis menunjukkan bahwa Budi Buchari memiliki kecenderungan radikal, ditunjukkan dari postingan tentang kekerasan di Timur Tengah seperti Suriah, Palestina, Turki, antipenista agama, antipembakar bendera, dan lainnya sebagainya. Ketika pemilihan usai, yang terpilih adalah Rizky Tri Utomo (FEB 2016) yang merupakan kader KAMMI.

Kuatnya KAMMI dalam lembaga dakwah tentu bukan sesuatu yang khas Undip. Di berbagai kampus, kecuali kampus UIN atau kampus Muhammadiyah, rohis selalu diisi oleh kader-kader KAMMI. Hal ini tidak mengherankan mengingat rahim awal terbentuknya KAMMI adalah lembaga dakwah kampus itu sendiri. Dalam data yang 
ditemukan penulis, setidaknya lima tahun terakhir ini Insani selalu diketuai kader dari KAMMI (lihat Tabel 1).

Tabel 1: Daftar Mas'ul Insani yang merupakan kader KAMMI

\begin{tabular}{|c|l|l|}
\hline Tahun & Nama Ketua & Jurusan \\
\hline 2013 & Lukas Santoro & Teknik Elektro 2009 \\
\hline 2014 & Rizal Pramudiarta & Akutansi 2010 \\
\hline 2015 & Budi Kusumo Putra & Teknik Kimia 2011 \\
\hline 2016 & Umar Syafiq & Ekonomi Bisnis 2013 \\
\hline 2017 & Din Fauzi M. & Psikologi 2014 \\
\hline 2018 & M. Rosyid Ridho & Ekonomi Bisnis 2015 \\
\hline 2019 & Rizky Tro Utomo & Ekonomi Bisnis 2016 \\
\hline
\end{tabular}

Sedangkan untuk BEM Undip, beberapa informan menyatakan bahwa sejak terbentuk tahun 1999 hingga 2018, struktur organisasi BEM selalu dikuasai oleh Kader KAMMI (lihat Tabel 2). Sulit untuk melakukan pelacakan yang pasti soal ini, namun pelacakan sosial media ketua BEM Undip yang pertama, yakni Fris Dwi Yulianto ditemukan bahwa akun Facebook bersangkutan seringkali mengunggah postingan yang berafiliasi dengan kelompok Tarbiyah, semisal postingan video "Orasi Politik Presiden PKS, Anis Matta". Beberapa pihak lain menyatakan setidaknya sejak 2013, Ketua BEM Undip adalah Kader KAMMI.

Tabel 2: Daftar Ketua BEM Undip yang merupakan kader KAMMI

\begin{tabular}{|c|l|l|}
\hline Tahun & Nama Ketua & Jurusan \\
\hline 2014 & Taufik Aulia Rahmat & Ilmu Komputer 2010 \\
\hline 2015 & Risky Haerul Imam & Kimia 2011 \\
\hline 2016 & Fawwaz Syaefullah & Ilmu Pemerintahan 2012 \\
\hline 2017 & Jadug Trimulyo Ainul Amri & Hubungan Internasional 2014 \\
\hline 2018 & Abdurrohman Hizbullah & Manajemen 2015 \\
\hline
\end{tabular}

Data di atas bisa jadi lebih panjang terkait kepemimpinan kader KAMMI, karena keterbatasan informasi yang detail, maka lima tahun terakhir inilah informasi yang sudah terkonfirmasi.

Baru pada Pemira 2018 (untuk Kepengurusan BEM 2019), Ketua BEM Undip yang terpilih bukan dari kader KAMMI. Pada Pemira 2018, bisa dibilang KAMMI mengalami kekalahan yang cukup telak. Dari 11 fakultas dan 1 sekolah vokasi, semua TPS menunjukkan kekalahan yang mencolok bagi calon presiden BEM dari kader KAMMI. Hanya Fakultas Psikologi saja yang dimenangkan oleh calon presiden BEM dari KAMMI (lihat Foto 1). 


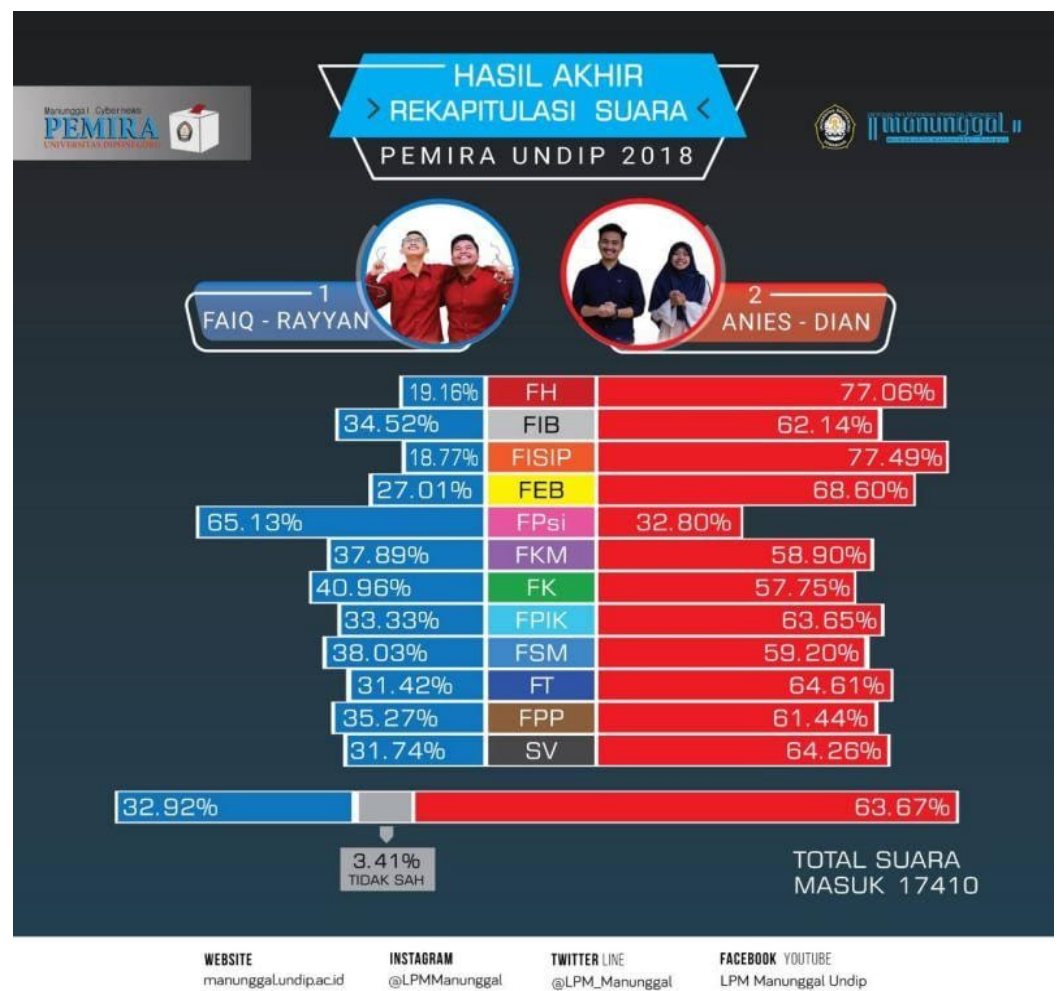

Foto 1: Hasil Rekapitulasi Suara Pemira 2018

Ada banyak faktor yang menyebabkan kekalahan KAMMI untuk pertama kalinya ini. Secara umum, faktor utamanya adalah sosok ketua yang diusung KAMMI kalah populer dengan lawan dari koalisi kelompok Cipayung, yakni HMI, PMII, GMNI dan kelompok non-organisasi yang relatif solid dan efektif dalam menjalankan mesin politiknya. Untuk menjelaskan faktor kedua ini, penulis akan mengulas di bagian selanjutnya terkait bagaimana kelompok Cipayung mempertahankan eksistensinya.

Sedangkan untuk lokus ketiga, yakni Masjid Kampus (Maskam) Undip, dinamika yang ada menunjukkan kenyataan yang tidak jauh berbeda dengan dua lokus sebelumnya, yakni posisi struktural organisasi juga dikuasi oleh kader-kader KAMMI. Sebenarnya, secara resmi, pengelola kegiatan di masjid ini adalah Takmir Maskam Undip. Semua penceramah untuk Sholat Jumat ditentukan oleh takmir, dan takmir ini kebanyakan diisi oleh para dosen. Kegiatan-kegiatan besar di Maskam Undip pun harus melewati penyaringan takmir. Namun, selain Takmir Maskam, terdapat organisasi Remaja Maskam AI Fatih, dan organisasi inilah yang jabatan strukturalnya selalu dikuasai oleh kader KAMMI.

Sebenarnya di Universitas Diponegoro, yang disebut dengan masjid kampus ada dua tempat. Pertama adalah Masjid Al-Fath atau dikenal dengan Masjid Diponegoro, terletak di Pleburan. Sedang yang kedua adalah Masjid Kampus (Maskam) Undip yang terletak di Tembalang. Masjid Al-Fath tidak akan banyak diulas di sini karena hampir sebagian besar aktivitas perkuliahan saat ini ada di wilayah Tembalang. Adapun fasilitas Undip di daerah Pleburan hanya digunakan untuk aktivitas perkuliahan S2 dan S3 yang 
jumlah mahasiswanya jauh lebih sedikit. Jadi, penjelasan aktivitas dan kegiatan di Masjid Al-Fath yang terletak di Pleburan untuk sementara tidak akan dikupas.

Dalam pengelolaan kegiatan di luar Sholat Jumat, atau kegiatan umum yang menggunakan fasilitas Maskam, ada 3 pihak yang terlibat, yakni Takmir Masjid, Remaja Masjid Al-Fatih, dan Insani. Takmir sebagian besar diisi oleh kalangan dosen. Pada kepengurusan 2018, Ketua Takmir Maskam adalah Ir. H. Nirmolo Supriyono dan Sekertaris Umumnya adalah Prof. Ir. Luthfy Djauhari Mahfudz, M.Sc, Ph.D. Sedangkan untuk remaja maskam Al Fatih, organisasi ini baru dibentuk tahun 2016 yang memiliki tujuan "menghidupkan masjid dengan menjadikan masjid sebagai pusat kegiatan mahasiswa Undip". Dalam penelusuran penulis, komposisi jabatan Al Fatih hanyalah eksodus jabatan dari Insani. Hal ini terkonfirmasi bahwa selama 2018-2019, Mas'ul (Ketua) Al Fatih adalah demisioner Ketua Insani. Muhammad Rosyid Ridho, mahasiswa FEB 2013, kader KAMMI, mantan Mas'ul Insani 2016, setelah demisoner kemudian menjadi mas'ul Al Fatih 2018. Kemudian Rizky Tri Utomo, mahasiswa FEB 2016, kader KAMMI, mantan mas'ul Insani 2019, setelah demisioner dari Insani kini terpilih sebagai Mas'ul Al-Fatih. Artinya, ketua Al Fatih cenderung diisi oleh mantan ketua Insani.

Baik Takmir, Al-Fatih dan Insani, memiliki peran penting dalam kegiatan di Maskam Undip. Apabila Lembaga Dakwah tingkat jurusan (LDJ) atau tingkat fakultas (LDF) akan mengadakan kegiatan, maka izin pertama harus diberikan oleh ketua Insani, kemudian diteruskan ke izin dari ketua Al-Fatih, baru izin dari ketua Takmir Maskam. Sedangkan untuk lembaga di luar lembaga dakwa kampus, maka hanya izin dari ketua Al-Fatih dan Ketua Takmir yang diperlukan, tanpa memerlukan izin dari Insani. Ini artinya, baik Insani dan Al-Fatih memiliki peran signifikan untuk melakukan filtering bagi kegiatan-kegiatan yang ada di Maskam.

\section{Bagaimana Kelompok Tarbiyah Meneguhkan Status Quo?}

Representasi kelompok Tarbiyah di Undip dalam hal ini adalah KAMMI. Organisasi ini lahir pada 29 Maret 1998, sesaat setelah acara Forum Silahturahmi Lembaga Dakwah Kampus (FS-LDK) ke-10 yang diselenggarakan di Universitas Muhammadiyah Malang (UMM). Dalam konteks Undip, kader-kader KAMMI telah menduduki berbagai pucuk pimpinan organisasi intrakampus, baik BEM maupun Rohis, di tingkat fakultas maupun universitas. Kader KAMMI memiliki semangat juang tinggi untuk selalu berdakwah di kampus karena mereka mengasosiasikan dirinya sebagai muslim negarawan. Bagi mereka, seorang pendakwah harus terlibat dalam politik, karena dengan cara itu syiar agama berlangsung dengan efektif. Kampus di posisikan sebagai kawah candradimuka sekaligus ladang amal. Jadi, berdakwah dan terlibat (perebutan) kekuasaan politik organisasi kampus adalah satu jalan yang harus ditempuh dalam kehidupan sehari-hari di universitas (wawancara dengan salah satu kader KAMMI). 
Pemahaman di atas muncul karena kader KAMMI memegang konsep Syumuliyatul Islam, yakni syariat Islam bersifat menyeluruh dalam aspek kehidupan. Rujukan ini diambil dari tokoh inspirasi mereka, yakni Hasan Al-Banna, khususnya referensi bacaan para aktivis Ihwanul Muslimin di Mesir, seperti Majmu'atu Rasail dan Manhaj Haraki. Dengan berbekal pemahaman itu, konsep muslim negarawan yang dirumuskan KAMMI menjadi pegangan dan spirit para kader. Ekspresi sebagai negarawan muslim ini mereka gelorakan bahkan pada publik secara luas di lingkungan Undip (lihat Foto 2).

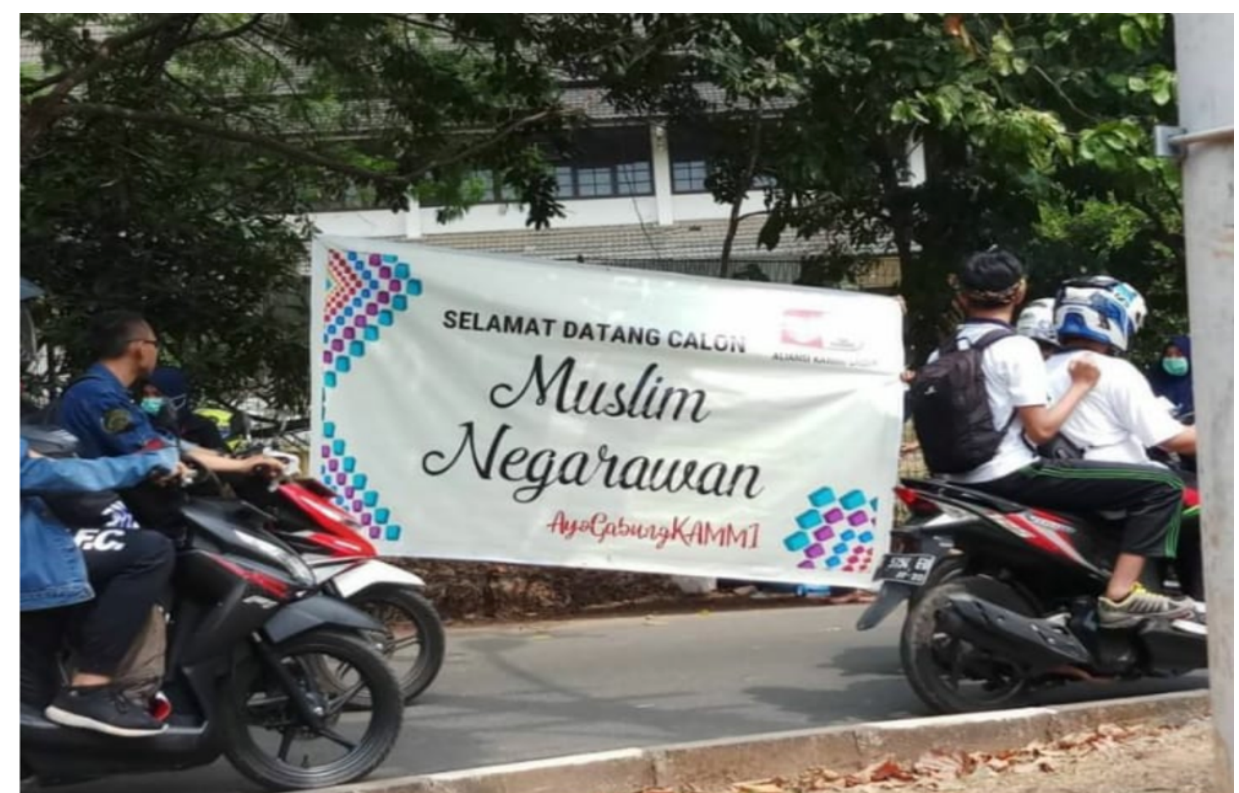

Foto 2: Spanduk KAMMI di lingkungan Undip Tahun 2018

Secara umum, karakter anak KAMMI bisa diidentifikasi dari kebiasaankebiasaannya. Kader kami akan menolak bersalaman dengan yang bukan muhrimnya. Artinya, kader KAMMI akan cenderung menghindar dari kebiasaan bersalaman jika bertemu teman yang berbeda lawan jenis. Sebagaimana penjelasan RS, salah seorang pengurus FKMM berikut:

\footnotetext{
"Ada kalanya mereka terpaksa bersalaman, terutama yang punya jabatan ketua oraganisasi. Namun, mereka pasti akan menyesali, dan beristighar kalau habis salaman dengan teman perempuan. Kadang ada perempuan yang tidak tahu kebiasaan ini, bertemu langsung mengulurkan tangan. Nah biasanya, anak KAMMI ada yang menolak tetapi ada juga yang bersalaman dengan terpaksa"
}

Selain tidak bersalaman dengan lawan jenis, karakter berkegiatan dengan memisahkan laki-laki dan perempuan (infishal) adalah karakter anak-anak KAMMI ketika membuat acara di kampus.

Dari sisi berpakaiannya, juga bisa dikenali, yakni celana polos-cingkrang dan baju koko. Bagi kader KAMMI yang sangat ideologis, karakter berpakaian semacam ini terus dilakukan. Mereka ke kampus dan berkuliah dengan pakaian semacam itu, meskipun 
tidak semua kader KAMMI melakukan hal tersebut. Selain berpakaian, kader KAMMI akan punya kecenderungan untuk tidak merokok, apalagi di depan umum. Merokok termasuk larangan yang harus dijauhi dalam kaderisasi di KAMMI.

Kultur Tarbiyah yang semacam itu adakalanya sudah terbentuk sejak SMA. Beberapa informan mengonfirmasi, mereka yang sekolah di SMA yang berideologi Ikhwanul Muslimin, seperti SMA Nurul Fikri (Magelang) dan MA Husnul Khotimah (Kuningan), ketika kuliah biasanya akan cenderung bergabung dengan KAMMI yang memiliki kesamaan ideologi. Para alumni itu memiliki organisasi yang selalu memberikan orientasi pada mahasiswa baru sesama alumni, dan organisasi itu cenderung berafiliasi dengan KAMMI karena kesamaan ideologi. Meski demikian, penulis juga menemukan ada beberapa informan tidak mau masuk KAMMI setelah menjadi mahasiswa karena merasa terlalu disetir oleh senior sesama alumninya.

Sedangkan untuk menjawab bagaimana kelompok Tarbiyah meneguhkan status quo-nya di Undip, ada beberapa analisis yang ditemukan. Pertama, mereka melakukan kaderisasi yang masif di berbagai lini, termasuk yang jarang dilakukan oleh organisasi ekstra lainnya. Jika dilihat dari tempat kaderisasinya, ada tiga jalur yang ditempuh KAMMI, yakni masjid, organsasi intra-kampus (Rohis, BEM, UKM, dan lain sebagainya), dan kos-kosan. Masjid adalah area kegiatan mentoring. Selepas melakukan sholat jama'ah, kelompok-kelompok kecil mentoring dilaksanakan. Dalam mentoring, mereka akan membahas berbagai hal seputar tema-tema keagamaan, dari soal ibadah, akhlak, hingga politik.

Aktifnya kader KAMMI menguasai organisasi intrakampus adalah untuk mendapatkan kader yang jauh lebih banyak. Ini bukan hal baru, sebab juga dilakukan oleh HMI, PMII, GMNI atau organisasi ekstra yang lainnya. Hanya, KAMMI memiliki agresifitas dan cerita sukses dalam merebut organisasi intrakampus lebih banyak dibanding dengan HMI, PMII, IMM, dan yang lainnya. Organisasi intrakampus yang paling efektif untuk mendapatkan kader KAMMI adalah BEM dan Rohis.

Analisis kedua untuk meneguhkan status quo, kader KAMMI akan membawa kultur KAMMI ke organisasi kampus yang telah mereka kuasai. Hal ini bisa dilihat dari beberapa temuan. Ketika sebuah organisasi dikuasai KAMMI, maka ada kecenderungan selama melakukan kegiatan, sebelum acara dimulai selalu diawali dengan tilawah Qur'an. Kebiasaan ini awalnya ada kebiasaan di internal KAMMI ketika akan mengawali kegiatan atau acara. Namun, ketika mereka berhasil duduk di pucuk pimpinan dan beberapa kursi strategis organisiasi, maka kebiasaan itu akan di bawa ke organisasi yang baru. Beberapa hal itu persis sebagaimana yang dilakukan pengurus Forum Keluarga Mahasiswa Muslim (FKMM) selaku Rohis Fisip, yang selama ini selalu dipimpin orang kader KAMMI. 
Tidak hanya itu, acara Senat Mahasiswa yang di ketuanya berasal dari KAMMI, juga pernah menggelar acara yang diawali dengan tilawah Qur'an. Selain tilawah Qur'an, gagasan yang mengatakan pakaian terbaik adalah celana polos-cinkrang dan baju koko juga sering diarahkan ketua organisasi Rohis kepada calon anggota/pengurus laki-laki. Kegiatan-kegiatan Rohis yang sudah dikuasai KAMMI biasanya juga selalu memisahkan (infishal) antara posisi duduk laki-laki dan perempuan.

Proses pembawaan kultur ini selain untuk meneguhkan posisinya dalam organisasi intrakampus, juga untuk menjaring kader yang lebih banyak. Sebagaimana dijelaskan oleh Muhammad (2015):

FKMM menjadi wadah bagi KAMMI untuk melakukan kaderisasi informal, yaitu dengan mengadakan liqo dan halaqah dimana selain untuk menambah ilmu mengenai kelslaman, juga dijadikan ajang kaderisasi bagi KAMMI dengan mengajak para peserta mentoring untuk ikut dalam Daurah Marhalah (DM) yang diadakan KAMMI.

Bukan rahasia lagi, aktifitas mentoring pada rohis kampus umumnya dilakukan oleh para pementor dari kader-kader KAMMI. Sebab, aktivitas mentoring inilah yang cukup banyak berkontribusi terhadap penambahan kader KAMMI.

Kultur semacam di atas akan tidak tampak bagi rohis yang tidak dikuasai oleh KAMMI. Ambil contoh Koordinator Kegiatan Islam (KKI) Fakultas Hukum, yang pengurusnya di dominasi oleh HMI dan PMII. Di Rohis KKI, kebiasaan tilawah sebelum memulai acara tidak ada. Mereka biasanya memulai dengan berdoa saja. Selain itu, rapat-rapat KKI juga dilakukan tanpa pemisahan; laki-laki dan perempuan bercampur (ikhtilat). "Kami melakukan biasa, tidak ada panggilan Ikhwan dan Akhwat, tidak ada pemisah laki-laki dan perempuan saat berkegiatan. Semuanya biasa saja, lancar-lancar saja," terang KR, mantan pengurus KKI.

Analisis ketiga dalam meneguhkan status quo, setelah organisasi dikuasai, maka kader KAMMI akan mengarahkan tata aturan organisasi agar menguntungkan kelompoknya. Adanya aturan dalam pencalonan ketua BEM Undip atau Rohis Fakultas untuk tidak merokok adalah salah satu buktinya. Hal ini berbeda jika organisasi belum mereka kuasai, aturan tidak boleh merokok semacam ini tidak pernah ada, misalkan pencalonan ketua BEM Fakultas Hukum atau pencalonan Ketua Koordinator Kegiatan Islam (KKI) Fakultas Hukum yang sama sekali tidak ada aturan calon ketua BEM adalah mahasiswa yang tidak merokok.

Tidak itu saja, kader KAMMI juga seringkali mengubah tata tertib dalam organisasi untuk mempertahankan status quo mereka. Misal, terkait syarat tingkatan Training Rohis (I hingga III) yang sering kali di syaratkan dalam pemilihan ketua LDF dan Insani. Ketika ada calon lain bisa dijatuhkan oleh syarat itu, mereka akan menaikan syaratnya (dari syarat memiliki training Tingkat II menjadi Tingkat III). Begitu juga sebaliknya, jika calon mereka terganjal syarat ini, maka proses penjaringan akan diperpanjang sampai si 
calon dari KAMMI memiliki sertifikat yang di maksud. Sebagaimana disampaikan RS, pengurus FKMM yang bukan kader KAMMI, bahwa:

\footnotetext{
"Pemilihan tahun sebelumnya (2016), ada calon ketua dari non-KAMMI di FKMM. Sedangkan kader KAMMI, belum ada yang memenuhi syarat, tepatnya belum memiliki sertifikat Training Rohis Tingkat II. Akhirnya, waktu penjaringan diperpanjang lama sekali hingga calon dari kader KAMMI sudah mendapat sertifikat. Anak KAMMI itulah yang akhirnya menjabat sebagai ketua FKMM 2017".
}

Adapun yang paling signifikan untuk mempertahankan status quo, tentu saja syarat harus memiliki sertifikat Latihan Ketrampilan Menejemen Mahasiswa (LKMM) Tingkat Madya Undip. Pelatihan ini berjenjang, yang artinya calon presiden BEM tidak mungkin berasal dari luar sistem sebelumnya.

Tabel 3: Tingkatan LKMM Bagi Calon Presiden BEM

\begin{tabular}{|l|l|l|}
\hline Jenjang & Penyelenggara & Peluang \\
\hline LKMM Tingkat Pra Dasar & HMJ & $\begin{array}{l}\text { Saat orientasi } \\
\text { mahasiswa baru }\end{array}$ \\
\hline LKMM Tingkat Dasar & BEM Fakultas & 1 kali di 11 Fakultas \\
\hline LKMM Tingkat Madya & BEM UNDIP & 1 kali dalam setahun \\
\hline
\end{tabular}

Dari tabel 3 di atas, maka ditemukan penjelasan bahwa hanya orang yang terlibat BEM sebelumnya saja yang bisa menjadi calon Presiden BEM Undip. Inilah yang menjelaskan kenapa KAMMI bisa mempertahankan status quo sangat lama. Karena mekanisme pencalonan presiden BEM sebenarnya cukup eksklusif, dimana hanya peserta yang lulus LKMM Tingkat Madya saja yang bisa mencalonkan diri. Padahal, penyelenggaraan LKMM ini hanya setahun sekali dan diinisiasi oleh BEM yang berkuasa sebelumnya. Hal ini cukup berbeda jika dibandingkan dengan sistem politik inklusif berbasis Partai Mahasiswa, sebagaimana dilakukan di UGM.

\section{Perlawanan Kelompok Cipayung terhadap Kelompok Tarbiyah}

Kelompok Cipayung ini merujuk pada gerakan multiorganisasi yang merumuskan “Kesepakatan Cipayung" pada Januari 1972. Beberapa organisasi tersebut diantaranya HMI (Himpunan Mahasiswa Islam), PMKRI (Perhimpunan Mahasiswa Katolik Republik Indonesia), GMNI (Dewan Pimpinan Pusat Gerakan Mahasiswa Nasional Indonesia), dan GMKI (Gerakan Mahasiswa Kristen Indonesia), dan terakhir PMII (Pengurus Besar Pergerakan Mahasiswa Islam Indonesia). Kelima organisasi ini juga memiliki eksistensi dan ikut mewarnai dinamika percaturan politik kampus di Undip. Meski bukan kelompok yang mampu mendominasi kepemimpinan organisasi intrakampus, namun eksistensi mereka masih cukup diperhitungkan. 
Kuatnya status quo KAMMI dalam kepemimpinan di BEM Undip, membuat sebagian dari kelompok Cipayung ini membentuk koalisi. Ketika menjelang Pemira 2018, HMI, GMNI, dan PMII dan beberapa mahasiswa non-organisasi ekstra yang menamai dirinya "Partikel Bebas" menyepakati sebuah koalisi bersama untuk "menghentikan" dominasi KAMMI di kepengurusan BEM 2019. Koalisi bersama ini bersepakat untuk mengusung Muhammad Anies Ilahi - Dian Fitriyani (Anies-Dian) sebagai calon yang akan bersaing dengan kandidat dari KAMMI, yakni Faiq-Rayyan. Pemilihan Anies-Dian dilakukan melalui fit and proper test berupa wawancara kedua kandididat dalam rapat besar yang dihadiri lebih dari 20 orang. Hal tersebut sebagaimana diungkapkan salah satu anggota Tim Anies-Dian bahwa:

\begin{abstract}
"Saat itu sebagian besar anggota koalisi hadir. Mereka melakukan wawancara pada kami berdua. Sebenarnya calonnya ada 3, namun yang satu mundur karena lebih ingin maju sebagai ketua BEM di fakultas. Wawancara terbuka, semua orang ikut bertanya, ada yang tanya bagaimana pasca pemilihan, sampai hal-hal yang tidak berhubungan kadang ditanyakan".
\end{abstract}

Kemenangan pasangan Anies-Dian tidak lepas dari strategi politik yang mereka gunakan. Setidaknya, ada dua strategi pokok yang mereka pakai, yakni strategi internal dan strategi eksternal. Dalam strategi internal, mereka berusaha mendistribusikan jaringan koalisi untuk terlibat dalam struktur kelembagaan Pemira, yakni Tim Yudisial (Mahkamah Pemira), Panitia Pemilihan (KPU), Badan Kehormatan Pemira. Pentingnya memasukkan anggota dalam tim tersebut, sebagaimana diungkapkan oleh salah satu pengurus BEM 2019 yang juga kader HMI.

\footnotetext{
"Selama ini, KAMMI selalu menang karena struktur Pemira selalu mereka pegang. Laporan pelanggaran pemira selalu tidak mendapat respon, seperti isu SARA yang menimpa salah satu calon pada Pemira 2017 yang tidak diproses. Berbeda jika kelembagaan itu diisi oleh orang-orang kita, ketika ada pelanggaran akan di proses. Seperti salah satu senator Undip (kader KAMMI) yang terbukti berkampanye terhadap salah satu calon. Padahal, aturan sudah jelas, senator mahasiswa sebagai steering comite dilarang untuk terlibat kampanye. Akhirnya senator mahasiswa itu diberhentikan".
}

Sedangkan untuk strategi eksternal, banyak sekali hal yang bisa dicatat, salah satunya adalah berkoalisi dengan tim sukses pasangan lain yang berkompetisi di Pemira tingkat fakultas. Tentu saja yang diajak berkoalisi adalah pasangan yang tidak ada unsur KAMMI di sana. Koordinasi dengan tim sukses pasangan di tingkat fakultas bertujuan agar calon yang maju di fakultas juga ikut menyokong dan mendukung calon yang berkontestasi di Pemira tingkat universitas. Selain cara di atas, strategi eksternal lain yang digunakan adalah menggaungkan kembali narasi ABK (Asal Bukan KAMMI) ke publik. Narasi ABK sebenarnya bukan diciptakan oleh koalisi ini, namun sudah ada sejak pemira-pemira sebelumnya. Koalisi ini hanya menangkap narasi tersebut untuk 
memenangkan calon yang mereka usung. Dengan strategi internal dan eksternal itulah, singkat cerita, akhirnya kandidat yang diusung KAMMI mengalami kekalahan dalam Pemira 2018 lalu.

Ada banyak faktor yang penulis amati mengapa calon yang di usung KAMMI mengalami kekalahan dalam Pemira 2018. Pertama, dari sisi kandidat yang di usung. Baik dari pihak KAMMI maupun koalisi Cipayung mengonfirmasi bahwa kandidat yang di usung KAMMI bukan sosok yang kuat. "Kalah Pemira karena memang calonnya kurang populer. Tahun 2018 ini, KAMMI kekurangan kader. Sebenarnya ada yang lebih bagus dari Faiq-Rayyan, namun beberapa memilih maju di fakultas," terang WS, pengurus KAMMI Undip. Timses Anies-Dian juga mengonfirmasi kenyataan yang sama bahwa, "Ketika nama Faiq diumumkan sebagai calon, jujur saya merasa bersyukur. Karena saya dengar namanya di angkatan dia sendiri saja kurang disukai. Beberapa pengurus BEM sebelumnya juga mengenalnya bukan orang yang kerjanya bagus".

Kedua, dari sisi media sosial (medsos). Ruang medsos adalah wilayah yang paling signifikan bagi berkembangnya narasi ABK. Di sosmed muncul berbagai official account (OA) Line yang terus menerus menggaungkan narasi ABK. Akun-akun tersebut bahkan memiliki ribuan follower dan nyaris semuanya menyerang KAMMI. Setidaknya ada 4 OA yang memiliki follower di atas seribu, yakni OA Line Partai Baskoro Raya, OA Line Aku Bukan Kammi, OA Line KAMMU PT UNDIP, OA Line Asal Bukan Kammu. Ketika penulis lacak, ternyata beberapa kalangan yang menggerakkan OA ini adalah mahasiswamahasiswa non-organisasi, meski beberapa diantaranya adalah kader organisasi ekstrakampus, seperti HMI, PMII, GMNI. Mereka terbentuk jauh sebelum koalisi pasangan Anies-Dian terbentuk. Beberapa OA inilah yang menciptakan polemik tentang calon presiden BEM dari KAMMI. Mereka mengemas postingan dengan gaya satir dan banyak sekali komentar yang masuk. Inilah yang membuat banyak mahasiswa nonorganisasi ekstrakampus akhirnya ikut berpartisipasi dalam Pemira, karena mereka mulai termakan narasi ABK yang dilakukan oleh beberapa OA Line di atas.

Ketiga, dari sisi karakter kelompok yang dicitrakan. Meskipun menunjukkan diri dengan citra kelompok mahasiswa yang Islami, dalam beberapa hal, ada kader KAMMI yang menggaungkan keislaman kelompoknya dengan mengekspresikan secara berlebihan. Sebagai contohnya, KAMMI beberapa kali memakai isu agama dalam Pemira, dan inilah yang melahirkan antipati di kalangan mahasiswa non-Islam maupun mahasiswa muslim yang moderat. Hal ini dikonfirmasi ketika Pemira 2017 (untuk kepengurusan 2018), terdapat calon ketua BEM, yakni Jonris P. Nainggolan yang kebetulan seorang non-muslim. Karena identitas itu, dirinya dipojokkan dengan isu agama selama proses kampanye. Dalam bahasa lain, ada suasana "Di-Ahok-kan" terhadap sosok Jonris P. Nainggolan. "Pemira yang menghasilkan kepemimpinan Mas Aab (Abdurrohman, Presiden BEM 2018) itu, dulu sangat panas. Isu agama dihembuskan 
dimana-mana, pesan-pesan di media sosial kencang agar tidak memilih pemimpin yang tidak seagama, dalilnya ini itu dan lain sebagainya," jelas salah satu aktivis HMI pada penulis.

Untuk tahun 2019 ini, tiga organisasi kelompok Cipayung, yakni HMI, PMII, dan GMNI bisa menduduki posisi struktural BEM Undip. Mereka juga bisa menguasai jabatan struktural untuk beberapa BEM tingkat fakultas. Namun, untuk rohis Insani, LDF, LDJ, maupun Remaja Masjid Al Fatif, kader-kader KAMMI masih mendominasi hingga sekarang. Meski tidak bisa mendominasi di organisasi dakwah intrakampus, kelompok HMI dan PMII tetap memiliki kaderisasi dan kajian-kajian keagamaan dalam organisasinya. PMII memiliki agenda rutin tahlilan setiap malam Jumat seusai sholat Isya di Maskam Undip. Selain kegiatan tahlilan, PMII bahkan memiliki kajian khusus dua minggu sekali untuk mempelajari kitab kuning, diantaranya seperti Kitab Fathul Qorib. Sedangkan HMI memiliki Pengajian Rutin Tafsir Al Quran setiap hari Selasa di rumah Dr. Suharnomo, salah satu senior HMI yang secara kebetulan juga Dekan Fakultas Ekonomi dan Bisnis Undip. Pengajian ini selalu mengundang ustadz atau tokoh-tokoh agama yang didatangkan sendiri oleh Dr. Suharnomo. Selain kajian keagamaan, baik HMI maupun PMII memiliki forum kajian rutin untuk membahas isu-isu politik kontemporer.

Selain kelompok ini, ada beberapa kelompok aktivis dakwah lain yang juga memiliki eksistensi di Undip, seperti IMM (Ikatan Muda Muhammadiyah), KMNU (Keluarga Mahasiswa Nahdlatul Ulama). IMM dan KMNU cenderung tidak banyak terlibat dalam percaturan politik kampus. Bukan karena IMM cenderung apolitis, namun lebih karena jumlah mereka yang relatif sedikit di kalangan mahasiswa. Untuk KMNU, diperkirakan memiliki jumlah lebih banyak dari IMM, namun kelompok ini sepertinya kurang begitu tertarik pertarungan di politik kampus. Kecuali terlibat politik kampus dan diskusi politik, kegiatan KMNU hampir sama dengan PMII, yakni tahlilan setiap hari kamis setelah Sholat Magrib dan Kajian Kitab Kuning setiap Sabtu pagi.

\section{Penutup}

Dari pemaparan di atas, kenyataan dominasi kelompok Tarbiyah dalam menduduki jabatan-jabatan strategis di organisasi intrakampus bukan terjadi karena tidak adanya kompetitor dari kelompok keislaman lain. Ada cukup beragam kelompok keislaman yang memiliki eksistensi di Undip, mulai dari PMII, HMI, KMNU, dan lain sebagainya. Mereka juga kelompok yang intens dalam dunia dakwah; memiliki beragam forum pengajian, bahkan diskusi seputar politik kontemporer. Posisi status quo yang disandang KAMMI sebagai kelompok Tarbiyah muncul bukan sekadar karena keaktifan mereka di masjid dan mengelola rohis, namun juga karena politik eksklusi yang mereka lakukan, baik eksklusi secara kultural maupun struktural. 
Eksklusi kultural terjadi dengan mengubah kebiasaan-kebiasaan organisasi intrakampus dengan kebiasaan kelompok Tarbiyah. Hal ini akan membuat tidak nyaman kelompok lain yang tidak satu kultur. Contohlah, mahasiswa dari kultur NU, mereka akan sedikit risih dengan kebiasaan panggilan "Ikhwan, Akhwat, Ukhti, Akhi" semacam itu. Sedangkan eksklusi struktural dilakukan dengan mengubah tata aturan organisasi, mulai dari larangan merokok bagi kandidat calon ketua dan syarat sertifikasi Training Mentoring. Ada diskripsi menarik tentang eksklusi kultural dan struktural yang penulis dapatkan dari salah seorang informan yang merasa dicurangi dalam pemilihan Ketua Rohis, "Syarat untuk menjadi ketua rohis itu bukan pernah ikut Training Mentoring III, tetapi pernah ikut Daurah Marhalah I". Adapun Daurah Marhalah adalah tahapan kaderisasi di organisasi KAMMI.

Meskipun demikian, penulis mengakui dinamika gerakan keislaman di Universitas Diponegoro terus berkembang hingga sekarang. Oleh karena itu, limitasi penelitian ini adalah hanya memotret dinamika politik yang terjadi di akhir 2018 dan medio 2019 saja. Di sisi lain, yang patut disayangkan juga, proses riset ini terkendala pada situasi libur akhir semester yang berakibat pada beberapa informan potensial tidak berhasil di wawancara. Dampaknya, cukup banyak perspektif dari pelaku kunci belum berhasil digambarkan secara lebih detail di artikel ini.

\section{Ucapan Terima Kasih}

Penulis mengucapkan terimakasih kepada Ilham Rosyid Hasibuan dan Muhammad Kholilurrohman yang telah menjadi asisten penelitian lapangan. Ucapan terima kasih juga kepada Tim CVE (Counter Violence Extremist) Universitas Nahdlatul Ulama Indonesia, Jakarta, atas workshop penelitian yang diberikan pada penulis.

\section{Pendanaan}

Penelitian ini didanai oleh LPPM Unversitas Nahdlatul Ulama Indonesia, Jakarta, di bawah skema riset nasional bertajuk, "Transmisi Ideologi Gerakan Keislaman pada Civitas Akademika Perguruan Tinggi di Jawa Tengah dan DIY".

\section{Daftar Pustaka}

Aidulsyah, F. (2016). Berebut Ruang Publik Sekolah Pasca Orde Baru: Studi Kasus Pertarungan Politik Ideologi di Kerohanian Islam (ROHIS). Jurnal Studi Pemuda, 5(1), 370-385.

Arrobi, M. Z. (2020). Islamisme ala Kaum Muda Kampus: Dinamika Aktivisme Mahasiswa Islam di Universitas Gadjah Mada dan Universitas Indonesia di Era Pasca Soeharto. UGM PRESS.

Azca, M. N. (2013). Yang muda, yang radikal: Refleksi sosiologis terhadap fenomena radikalisme kaum muda muslim di indonesia pasca orde baru. Jurnal Maarif, 8(1), 
14-44.

BBC. (2016). Bahrun Naim, “Dalang” Serangan Jakarta Tamatan Ilmu Komputer. Retrieved from https://www.bbc.com/indonesia/berita_indonesia/2016/01/160115_indonesia_b ahrun

Darmawati, E. (2013). Aktivitas Mahasiswa Kelompok Dakwah Tarbiyah Ikhwanul Muslimin (Studi Tentang Konstruksi Sosial Keagamaan Pada Aktivis Dakwah Mahasiswa Universitas Airlangga). AntroUnairDotNet.

Fajar, S. (2017). Psychological Well-being Pada Aktivis Dakwah Kampus. Character: Jurnal Penelitian Psikologi., 3(3).

Husin, L. H. (2014). Gerakan Mahasiswa Sebagai Kelompok Penekan: Keluarga Mahasiswa UGM dari Masa Orde Lama hingga Paska-reformasi. Yogyakarta: PolGov.

Isnaniah, S. (2015). Kajian Sosiolinguistik Terhadap Bahasa Dakwah Aktivis Dakwah Kampus (ADK) Surakarta. KARSA: Journal of Social and Islamic Culture, 21(2), 270284.

Iswanto, A. (2017). Ideologi dalam Literatur Keagamaan pada Aktivis Dakwah Kampus dan Kajian Islam di ITB Bandung (The Ideology and Transmission of Religious Literature In Da'wah Activists and Islamic Studies in ITB Bandung). Jurnal SMART (Studi Masyarakat, Religi, Dan Tradisi), 3(1), 13-26.

Kamim, A. B. M., Azizi, A. N., Pratama, D. A., Haekal, L., \& Santoso, D. R. (2018). Kontestasi di Arena Dakwah Kampus: Studi Atas Strategi Aktivis Dakwah Fakultas dan Kampus Untuk Memobilisasi Sumber Daya Dakwah di Universitas Gadjah Mada. Hikmatuna, 4(2), 183-203. https://doi.org/10.28918/hikmatuna.v4i2.1308

Kompas.com. (2018). Sabtu Mengejutkan di Universitas Riau, 3 Terduga Teroris dan Bom yang Dirakit di Kampus. Retrieved from https://regional.kompas.com/read/2018/06/03/09411991/sabtu-mengejutkandi-universitas-riau-3-terduga-teroris-dan-bom-yang-dirakit?page=all

Mediani, M. (2017). Kaum Terdidik dalam Pusaran Ideologi "Anti-Pancasila." Retrieved from https://www.cnnindonesia.com/nasional/20170724064103-20229829/kaum-terdidik-dalam-pusaran-ideologi-anti-pancasila

Munip, A. (2012). Menangkal Radikalisme Agama di Sekolah. Jurnal Pendidikan Islam, 1(2), 159-181.

Rofiq, N., \& Bhakti, I. S. G. (2018). Persepsi Mahasiswa Aktivis Lembaga Dakwah Kampus Universitas Tidar tentang Empat Pilar Berbangsa dan Bernegara, serta Gerakan Islam Radikal. Ta'dib: Jurnal Pendidikan Islam, 7(2), 498-509.

Setiawan, D. (2018). Ini Pesan Menristekdikti ke Rektor Undip Soal Guru Besar Diduga Berpaham Radikalisme. Retrieved February 20, 2019, from https://www.tribunnews.com/regional/2018/06/26/ini-pesan-menristekdikti-kerektor-undip-soal-guru-besar-diduga-berpaham-radikalisme 
Tahir, Q., \& Cangara, H. (2016). Masjid Kampus sebagai Media Komunikasi Aktivis Dakwah dalam Pembentukan Karakter Mahasisw A. KAREBA: Jurnal IImu Komunikasi, 3(3), 186-192.

Trisno, A. (2010). Perbedaan Motivasi Berprestasi Antara Mahasiswa Aktivis Dan Non Aktivis UKM Kerohanian Di Universitas Merdeka Malang. Jurnal Psikologi Tabularasa, 5(2).

Widyaningsih, R., Sumiyem, S., \& Kuntarto, K. (2017). Kerentanan Radikalisme Agama di Kalangan Anak Muda. Prosiding, 7(1).

\section{Tentang Penulis}

Hendra Try Ardianto adalah Dosen Departemen Politik dan Pemerintahan, Fakultas Ilmu Sosial dan IImu Politik, Universitas Diponegoro. Penulis memiliki fokus riset pada kebijakan publik, studi demokrasi dan gerakan sosial. 